\title{
Evaluating English Module: Guidance to Help Develop Ideas for Writing
}

\author{
Tg Nur Liyana Bt Tengku Mohamed Fauzi \\ 1Universiti Teknologi MARA Kelantan \\ Rohazlyn Bt Rosly \\ Universiti Teknologi MARA Kelantan
}

Muna Liyana Bt Mohamad Tarmizi

Universiti Teknologi MARA Selangor

Nur Syamimi Bt Zahari

Abstract

Universiti Teknologi MARA Selangor

\begin{abstract}
This study focused on the evaluation of a module developed based on the current Form Three English textbooks. The module consists of different themes from the textbooks, developed to provide guidance for both teachers and students. The aim was to help generate ideas for English writing among the Malaysian secondary school students. The subjects involved were a total of 12000 students of Form Three and Form Four students from thirty schools in Kedah identified as the low performing schools in English subject in the PT3 exam 2014. The students were first identified and categorized into two groups of different English proficiency level known as stronger students and weaker students. The module came in two sets, Set 1 (red stripe) for the stronger groups of students and Set 2 (blue stripe) for the weaker groups. Each one contained 28 writing exercises of different themes based, other than samples of expressions, phrases, idioms and common transitional words to help get the students familiarize with English writing. These sets comprised of the same contents and activities but with different methods with closer guidance for the weaker groups and challenge for the stronger ones. The main reason was to eliminate stress and encourage students' participation. Evaluation was made on the students' performance based on their assessment results. Overall, Form Three students recorded significant increase in their results, while Form Four students' performance was also encouraging with the graph showing progression from the initial TOV to Mid-year Test as well as in the final exam results.
\end{abstract}

Keywords: writing, guidance for writing, ideas for writing, writing module, English writing

\section{Introduction}

There has been an extensive investigation for over a decade on the low English language literacy among Malaysian learners, which has risen the question why are there still very high number of students who do not seem to be able to achieve reasonable English proficiency (Normazidah, Koo \& Hazrita, 2012). In spite of the utmost commitment by the government and different agencies in addressing this issue, it is important for the authorities to observe the fundamental roles of teachers and ESL learners. One of the main problems faced by the Malaysian secondary school teachers of English as a foreign language is how to improve writing proficiency, with other components are also very much challenging. Educators at secondary schools are not only responsible for training the learners to develop English communication. They also have to make sure their students English proficient before completing school. Thus, they are dealing with not only the learners' lack of proficiency in the basic grammar, but also their reluctance to speak and write in English due to lack of motivation and low self-efficacy. Besides, although students streaming is a common practice in schools here, but students in the same class do not always have the same level of English ability. In effect, the present report is looking at the effectiveness of a module which is promoting cloze procedure method to help teachers confronting both stronger and weaker students in the same class without neglecting one or the other. This evaluation is aimed at discovering evidence that cloze procedure is a good teaching tool to teach from the basic structure of language to the more complex ones, while helping learners to become a better writer for various purposes. Not only that, educators can also stimulate reading and speaking activities in the classroom concurrently based on the content in the module. 


\section{Literature Review}

\subsection{Learners in Mixed-ability Classroom}

In Malaysian primary and secondary schools, students streaming is an established management strategy that addresses students' ability differences (Mansor, Maniam, Hunt \& Nor, 2016). Although students are categorized based on their achievement in examinations, but students in the same classroom may have different English proficiency level. These researchers (Mansor et al., 2016) stated that as this practice is giving overemphasis on exam orientation, which results in low self-esteem and lack of achievement motivation, it also increases peer pressure that hinders students to set achievable goals.

\subsection{Use of Modules as an Alternative Tool in ESL Classroom}

Previous researchers mentioned that learners are having problems not only in expressing themselves systematically and logically (Nardo \& Hufana, 2014), but also in putting words in the right order, which can be credited to their unfamiliarity with the sentence structure of English language. Therefore, it is important to acknowledge that the quality of instruction received by the learners is a major determinant to improve their writing skills (Trioa \& Graham, 2003). Besides, it often happens that learners could not relate to the teachers' instruction mostly because they are lack of motivation to do so. Consequently, it is recognized that the students need to be provided with the necessary materials (Waquey, 2012) and the use of modules could be an alternative tool for learning and also for learners' satisfaction (Nardo \& Hufana, 2014).

\subsection{Bandura's Social Cognitive Theory in Cloze Procedure Method}

Social Cognitive Theory or SCT used in psychology, education and communication mentions that parts of an individual's knowledge gain can be directly related to 'observation'. In this context, students were encouraged to 'observe English writing' and register the grammar and structure used in a cloze passage. During the 'observation', students do activities like filing in blanks with the words and phrases provided, and give meaning to each word and phrase according to the context (contextual clue). As stated in the theory (Bandura, 1977), when people observe 'a model' doing a behavior (in this case, students observe ideas and contents in a partially completed passage) and they observe 'the consequences' of that behavior (after they have filled in the blanks with the words/phrases), they should remember 'the sequence' and use the information they have gained as the guide to 'subsequent behaviors' (use of ideas and contents in English while doing other activities). Other than that, through observation of a model can also prompt the observer to 'participate in behavior they have learned' which, in this case, could be producing his/her own piece of writing based on topics related to the ones they have 'observed'.

\section{Methodology}

The collection of data began with a series of activities carried out within five months from May to October 2015. However, the actual result was only obtained two months after the program ended. The program began with teachers training, initiation of take-off value (TOV) based on the most recent examination results which data was obtained from the State Education Department (JPN) in Kedah. The TOV was used to set the expected target result (ETR). Teachers were then directed to begin their teaching and learning activity in schools using the module. In the effort to make sure each and every participating school adhere to the instructions and program requirements, one facilitator among the trainers was sent to perform an observation at each school, and was required to report on the use of module and students' feedback. After two months, the first result was obtained from the mid-year test for learners' performance observation purpose. Finally, the end result was gathered after the final examinations and here, again, a comparison was made against the TOV and the midyear test.

In the five months program, 12000 students were involved with not less than 120 teachers from two districts in Kedah, Malaysia, namely Sungai Petani and Kulim/Bandar Baharu. During the visits, the facilitators conducted activities with the students involved. This was done to ensure that each school was following the plan regarding the use of module within the set period. Part of the overall findings is based on the students' performance in examinations, as shown in the graphs. 


\section{Analysis}

Students' performance was reflected in bar graphs. Since there were 30 schools involved, here is the overall achievement of both Form Three and Form Four.

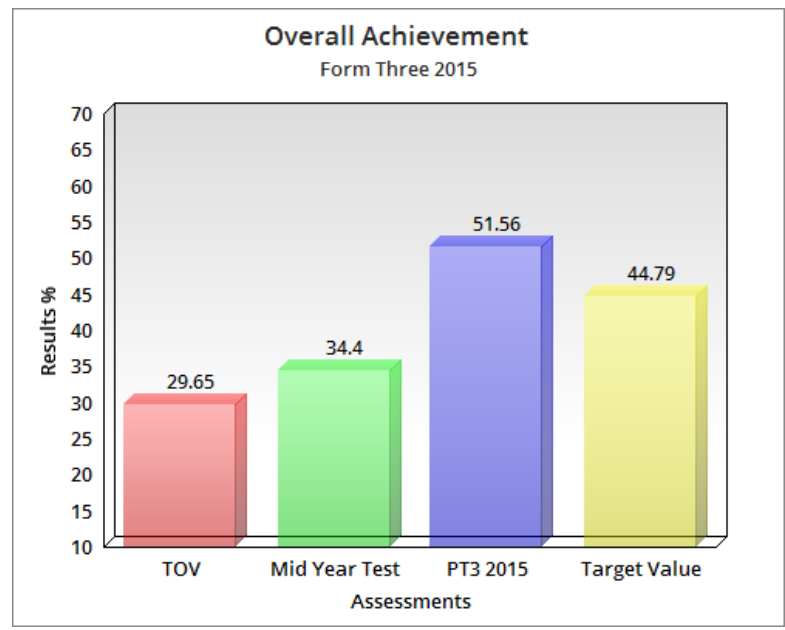

Figure 1.2: Overall Achievement of Form Three Students in Kulim/Bandar Baharu and Sungai Petani

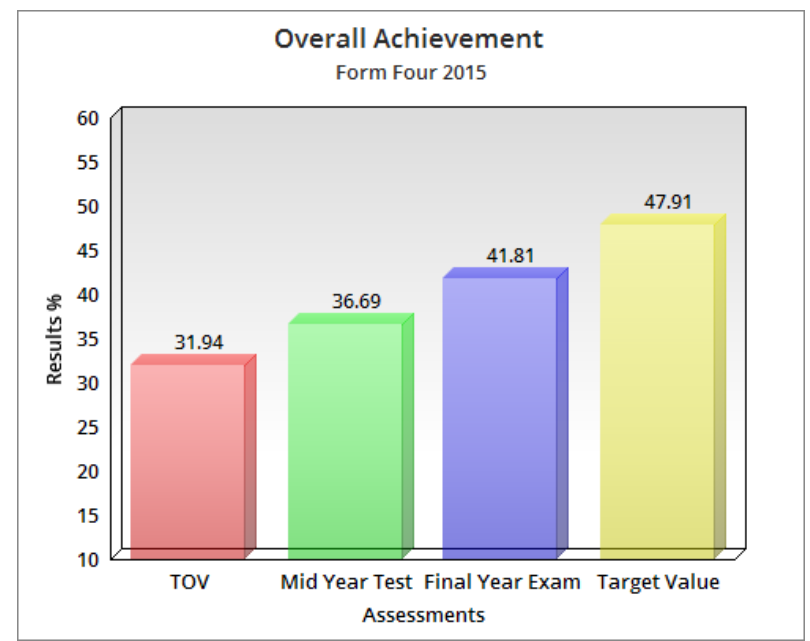

Figure 1.3: Overall Achievement of Form Three Students in Kulim/Bandar Baharu and Sungai Petani

\section{Result and Discussion}

It is observed that the overall improvement up to $51.56 \%$ (PT3) and $41.81 \%$ (Form 4) are significant although the latter shows a lower percentage than the TOV. Prior to that, participants who are among the ESL learners have shown improvement in their performance based on the increment in the passing rate in mid-year test 2015. The increase passing rate is related to the effectiveness of the module and the effort from the teachers in executing the teaching plan. Throughout the program, several changes and add-ons had been made in the initial plan to suit the needs and to solve occurring issues. For example, after the first visit, the team saw the need for supplementary activities as the continuation to the activities in each part of the module. As Block (1991) suggested, 'contextualization' is an important benefit of teacher-produced 
materials. Therefore, as the module-maker was an experienced teacher herself, she was able to make those activities useful for everyone involved; the trainers, teachers and students.

It is important to note the factors that distinguish the module used in the program from other teaching materials. Firstly, every chapter in the module is begun with a cloze procedure, where learners are supplied with ideas and contents based on specific themes. They are required to fill in the blanks with the words provided. This is to encourage reading and writing, without straining the learners with things beyond their ability. It is also recognised that instigating a chapter with a cloze procedure is a great help for them. They are prepared with the context for ideas, exposed to English sentence structures which help them to develop familiarity with the language and reduce first language interference. Secondly, the activities constructed in each part of the module are particularly developed as a continuation from the first activity. Students are exposed to various tasks like impromptu speech, forum, role-play, news reading, word search and contextual clues, to enhance their speaking, reading, listening, and even writing skills. More importantly, they are encouraged to reuse the ideas and contents given in the cloze procedure in the follow-up activities. Here, again, students are not strained with the trouble in searching for ideas and sentences. They learn to use existing ideas and sentences, and expectantly able to expand their language ability through the practice. Finally, teachers are able to teach grammar and tenses, and get the learners to find examples in the passages available in the module. Each grammar lesson is contextual based, where examples are extracted from the passage initially given in the form of cloze procedure. These activities using the same contents are named as 'purposeful recycle' which is found to help learners to improve their learners' language ability. Learners are found to be less anxious encountering words, phrases and sentences they are familiar with.

\section{Conclusion}

There are many studies discussing on the learners' perceptions about their difficulty in learning English language (Naginder, 2006; Nor Hashimah Jalaludin, Norsimah Mat Awal \& Kesumawati Abu Bakar, 2008), and intense debate on the low selfefficacy in English classrooms (Parilah, Wan Hamiah, Rosseni, Aminuddin \& Khalid, 2011; Sawyer, Graham \& Harries, 1992). The findings notified in this report should provide another angle to look at in the discussions pertaining to English teaching and learning among the ESL learner. Conclusively, the activities developed and carried out throughout the five months program are corresponding to scaffolding defined by Wood, Bruner and Ross (1976) that encourages the provision of the support for the students, which is removed gradually as learners gain their ability. Further research is needed to extend this method to learners of different education level.

\section{References}

[1] Bandura, A. (1977). Social learning theory. New York: General Learning Press.

[2] Block, D. (1991). Some thoughts on DIY materials for the world: A great compromise. In B. Tomlinson (ed.), Materials development in language teaching, 116-129. Cambridge: Language Teaching Library, Cambridge University Press.

[3] Naginder Kaur. (2006). Non-autonomy and low-English proficiency among Malaysian students: Insights from multiple perspectives. In Kamisah Ariffin, Mohd. Rozaidi Ismail, Ngo Kea Leng, \& Roslina Abdul Aziz. (Eds.), English in the Malaysian context. 21-34. Shah Alam: University Publication Centre (UPENA) UiTM.

[4] Ma. Theresa B. Nardo, \& Esther R. Hufana. (2014). Development and evaluation of modules in technical writing. American Journal of Educational Research, 2(6), 341-350.

[5] Mansor, A., Maniam, P., Hunt, M., \& Nor, M. (2016). Benefits and disadvantages of streaming practices to accommodate students by ability. Creative Education, 7, 2547-2558.

[6] Normazidah Che Musa, Koo Yew Lie, \& Hazita Azman. (2012). Exploring English language learning and teaching in Malaysia. GEMA: Online Journal of Language Studies, 12(1), 35-51.

[7] Nor Hashimah Jalaludin, Norsimah Mat Awal, \& Kesumawati Abu Bakar. (2008). The mastery of English language among lower secondary school students in Malaysia: A linguistic analysis. European Journal of Social Sciences, 7(2), 106-119.

[8] Sawyer, R., Graham, S., \& Harris, K. R. (1992). Direct teaching, strategy instruction, and strategy instruction with explicit self regulation: Effects on learning disabled students' compositions and self-efficacy. Journal of Educational Psychology, 84, 340352.

[9] Trioa, G. A., \& Graham, S. (2003). Effective writing instructions across the grades: What educational consultant should know, Journal of Educational and Psychological Consultation, 14, 75-89.

[10] Waguey, L. (2012). Effectiveness of Task-Based Instructional Materials in Developing Writing Skills of BS Fisheries Freshmen. Unpublished Dissertation. Benguet State University.

[11] Wood, D. J., Bruner, J. S., \& Ross, G. (1976). The role of tutoring in problem solving. Journal of Child Psychology and Psychiatry, 17(2), 89-100. 
[12] Parilah M. Shah, Wan Hamiah Wan Mahmud, Rosseni Din, Aminuddin Yusof, \& Khalid Mat Pardi. (2011). Self-efficacy in the writing of Malaysian ESL learners. World Applied Sciences Journal 15 (Innovation and Pedagogy for Lifelong Learning), 8-11. 